AUTHOR'S EDIITION.

DEPARTMENT OF THE INTERIOR.

UNITED STATES GEOLOGICAL AND GEOGRAPHICAL SURVEY.

F. V: HAYDEN, U. S. Geologist-in-Charge.

\title{
FOSSIL FORESTS
}

OF THE

\section{VOLCANIC TERTIARY FORMATIONS}

OF THE

\section{YELLOWSTONE NATIONAL PARK.}

BY

\section{W. H. HOLMFS.}

EXTRACTED FROM THE BULLETIN OF THE SURVEY. VOL. V, NO. 1. 



\section{Art. VII.-Wossil Forests of the Volcanic Tertiary For- mations of the Yellowstone National Farli.}

\section{By W. H. Holnmes.}

The prevalence of extraordinary volcanic activity throughout that part of the Tertiary age represented by the post-Cretaceous rocks of the Yellowstone region has given to them a most unique and interest. ing character. So destitute of animal remains are they, and so unlike the formations of the age in other parts of the Rocky Mountain region, that, notwithstanding the frequent visits of geologists, no divisions into sub-groups have been made, and no more definite appellation for the whole group has been found than the "Volcanic Tertiary"; this name, although so general, is singularly appropriate, and, in the absence of specifie determinations, may be used to designate the entire group of Tertiary strata in the Park district.

It is not my intention in this brief notice to attempt the classification or correlation of these strata, but to give a brief account of some very remarkable features brought to light by last year's explorations.

In the valley of the East Fork of the Yellowstone River, where this peculiar group of rocks is typically developed, they have a thickness of upwards of 5,000 feet. The prevailing materials which enter into their composition are fragmentary volcanic products, which have been apparently redistributed by water, and now form breccias, conglomerates, and sandstones. It has been noticed by nearly all visitors that these strata contain a great abundance of silicified wood, and in a few cases trunks of trees in situ have been reported. The lowest observed occurrence of the strata of this group is in the valley of the main Yellowstone, between the first and second cañons, at an elevation of about 5,000 feet above the sea. They are also finely developed in the Gallatin Range to the west of this valley, and about the sources of Cañon and Boulder Creeks reach a thickness of between 3,000 and 4,000 feet. At a number of points corering this entire thickness, masses of silicified wood occur, and near the divide at the head of Boulder Creek silicified trunks, many feet in height, and of gigantic proportions, stand in the identical strata in which they grew, the crumbling conglomerates having wathered away, leaving them standing upright along the steep slopes of the mountain. In general, these strata are horizontal. The bedding is often heary, and in places not well marked; sub-aërial voleanic deposits apparently alternate to some extent with the sub-aqueous.

Three miles above the mouth of Gardiner's River, in similar strata, there 
are a number of silicified trunks in situ, most of which occur in a stratum of sandstone that lies directly upon the eroded surface of a series of mica-schists that belong to the metamorphic range north of the Yellowstone River. This is at an elevation of 6,000 feet.

On the south side of the third cañon, opposite the mouth of Hell Roaring Creek, is a massive promontory composed of conglomerates, in which are very numerous intercalated beds of sandstones and shales. In the steeper faces of this promontory, many fine trunks are exposed. In $187:$, Dr. Peale obtained some very perfect specimens of fossil leaves from these beds, on the Elk Creek side, which were determined by Professor Lesquereux to be of Eocene types. The walls of the cañon in the ricinity of Hell Roaring Creek are formed of the same series of rocks, which occur also at a number of points on the river between Elk Creek and the lower falls.

In the valley of the East Fork, the sedimentary formations of the Volcanic Tertiary reach their maximum developement. Here they rest upon the unevenly eroded surfaces of the palæozoic and granite rocks, and form a great part of the mountain ranges that enclose the valley. They are horizontal and apparently conformable throughont the entire thickness of 5,500 feet. The greater part of this immense group of strata is filled with the silicified remains of a multitude of forests.

The section given in the accompanying plate occurs in the north face of Amethyst Mountain, opposite the valley of Soda Butte Creek, and includes upwards of 2,000 feet of strata. The bed of the river is at an elevation of 6,700 feet above the sea, and the summit of Amethyst Mountain, 9,400. On the north side of the valley, near the month of Soda Butte Creek, there are between 300 and 400 feet of Carboniferons strata exposed along the base of the mountain slope. On the soutl side, occasional ledges of limestone appear above the detrital deposits. 'Thin sheets of basalt cover the flat part of the valley, which is here less than a mile in width.

The north face of Amethyst Mountain does not present as abrupt a profile as that given in the section, the middle part only being so precipitous. At the base and top there are comparatively gentle slopes; nevertheless, the actual stratigraphical conditions are truthfully represented.

As we ride up the trail that meanders the smooth river-bottom, we have but to turn our attention to the cliffs on the right hand to discover a multitude of the bleached trunks of the ancient forests. In the steeper middle portion of the mountain face, rows of upright trunks stand out on the ledges like the columns of a ruined temple. On the more gentle slopes farther down, but where it is still too steep to support regetation, sare a few pines, the petrified trunks fairly cover the surface, and were at first supposed by us to be the shattered remains of a recent forest.

In ascending one of the steep spurs that project from the main wall, the strata were found to consist, toward the base, of shales and fine- 


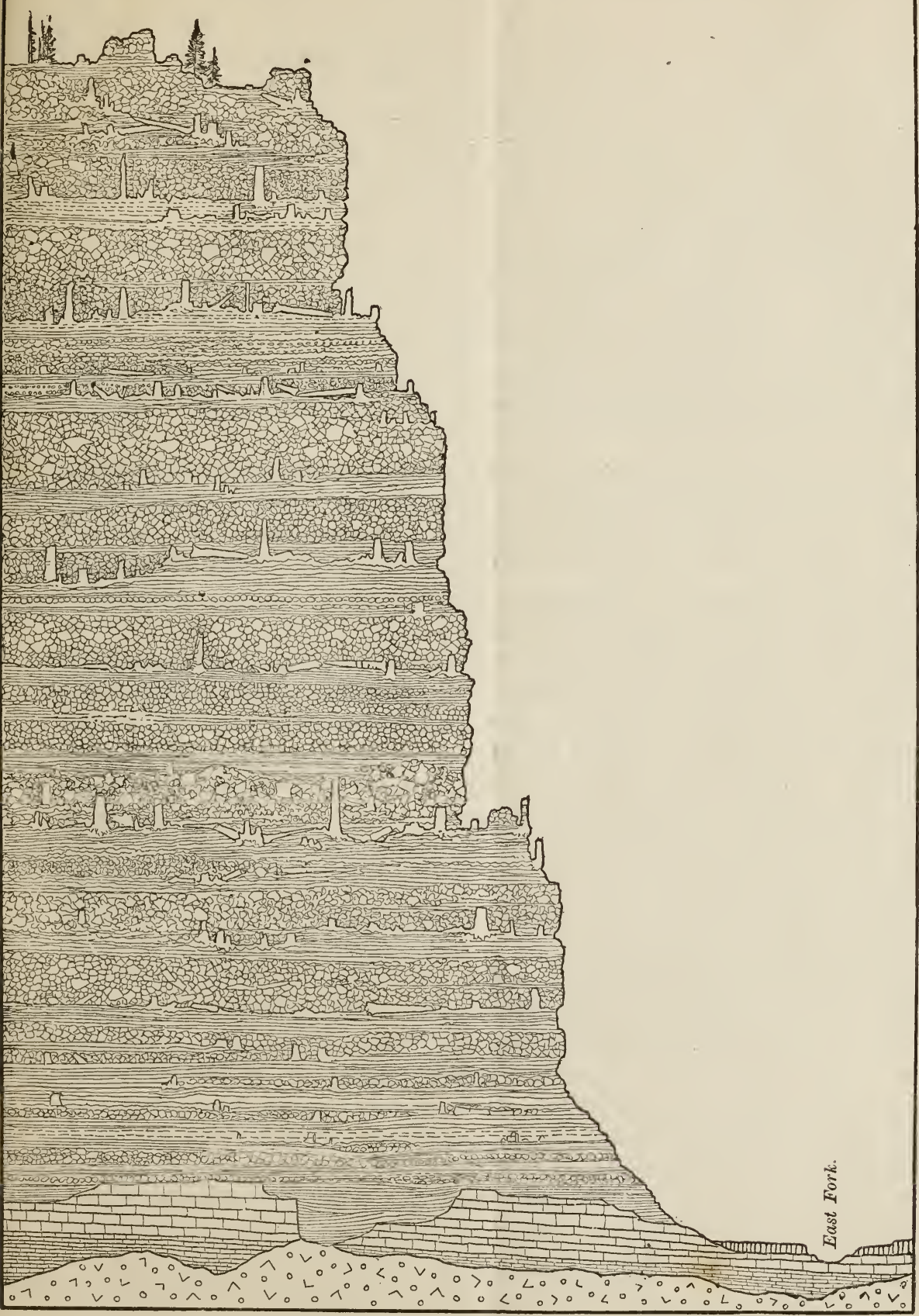

FIG. 1.-Section in the north face of Amethyst Mountain. 
grained sandstones. Higher up conglomerates occur, and still higher coarse conglomerates and breccias prevail. Interbedded with the massive, irregular beds of the latter rocks are always thin layers of sandstones and shales. The sandstones are fine-grained, thinly bedded, and contain more or less tufaceous material. Their prevailing color is greenish and greenish-gray. They are apparently composed chiefly of materials derived directly or indirectly from volcanic sources. In no case are pebbles of quartz or other granitic constituents found in either the sandstones or conglomerates.

The exposures of strata in the first three or four hundred feet at the base are not good, and but few of the silicified trunks appear above the covering of regetation. At the height of 500 feet, the occurrences become very numerous, and the great size and fine state of preservation of many of the trunks was a matter of much surprise. Prostrate trunks, 50 and 60 feet in length, are of frequent occurrence, and not a few of these are as much as 5 or $\mathbf{6}$ feet in diameter.

The standing trunks are generally rather short, the degradation of the compact enclosing strata being so slow that the brittle trunks break down almost as fast as they are exposed. In many eases the roots are exposed, and may be seen penetrating the now solid rock with all the original ramifications One upright trunk, of gigantic proportions, rises from the enclosing strata to the height of twelve feet. By careful measurement it was found to be ten feet in diameter, and as there is nothing: to indicate to what part of the tree the exposed section belongs, the roots may be far below the surface, and we are free to imagine that there is buried here a worthy predecessor of the giant Sequoias of California. Although the trunk is hollow, and partly broken down on one side, the woody structure is perfectly preserved, the grain is straight, and the circles of growth distinctly marked. The bark, which still remains on the firmer parts, is four inches thick, and retains perfectly the original deeply lined onter surface. Specimens of the wood and bark were collected, but no microscopic examinations have been made. It is clear, however, that the tree was not a conifer. The strata which enclose this trunk are chiefly fine-grained greenish sandstones, indurated clays, and moderately coarse conglomerates. They have Deen built around it as it stood in comparatively shallow, but doubtless quiet waters. As would naturally be expected, these strata contain many vegetable remains: branches, rootlets, fruits, and leaves are extensively enclosed. One stratum of sandstone that occupies a horizon nearly on a level with the present top of the giant tree contains a great variety of the most perfectly preserved leaves. Such specimens as we were able to bring away with us have been submitted to Professor Leo Lesquereux for. identification. They are found by him to belong to the Lower Pliocene or Upper Miocene, and correspond in a number of their species with the Chalk Bluffs specimens of Professor Whitney. They include- 


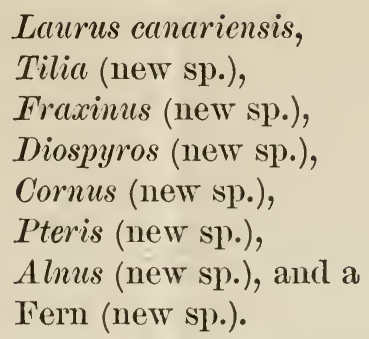

It will be observed that most of these species are new, which was also the case with the collection of Professor Whitney. It is also worthy of remark that none of the genera are identical with those of the Elk Creek locality previously mentioned. The stratigraphical relations of the two localities cannot easily be made out, as they are separated by fifteen miles of broken country in which the strata are obscured by igneous flows and Quaternary drift. The Elk Creek strata are lower by fully one thousand feet.

As far above the leaf-bearing horizon as I was able to ascend, the silicified trunks were very numerous and well preserved, and, by the aid of a field-glass, others could be detected in all parts of the cliff to the highest stratum.

At another point, nearly a mile farther east, I climbed the rugged walls of the mountain for the purpose of examining a number of large trees that were visible from below. Trunks and fragments of trunks were found in great numbers and in all conceivable positions. In most eases the moody structure is well preserved, the trunks have a tendency to break in sections, and on the exposed ends the lines of growth, from center to circunference, ean be counted with ease. In many cases the wood is quite completely opalized or agatized, and such cavities as existed in the decayed trunks are filled with beautiful crystals of quartz and calcite. Our party was so fortunate as to procure some very handsome specimens of amethyst and ferruginous quartz. It is a matter worthy of observation that nearly all of the beantiful crystals that occur so plentifully in this region have been formed in the hollows of silicified trees. The same fact has been noticed in regard to similar crystals in many parts of the West, and notably in the case of the smoky quartz of the Pike's Peak region in Colorado.

The silicifying agents have been so umusually active in the strata of the Volcanic Tertiary that not only are all organic remains thoroughly silicified, but all cavities in the loosely bedded rocks and all fracturelines in the strata are filled with chalcedony or other forms of quartz.

On reaching the heavily bedded conglomerates of the upper third of the cliff, I found the trees still more perfectly preserved. Many of the trunks are twenty and thirty feet in height. Their roots are in most cases imbedded in the layers of finer-grained materials, in which they grew, while the battered and branchless trunks are encased in the coarse conglomerates and breccias. These latter rocks are composed chiefly of Bull. v, $1 \longrightarrow 9$ 
basaltic fragments, many of which are of great size; there is, however, always enough tufaceous and other fine-grained material to fill in the interstices and act as a cement. These beds are massive and irregular, and seem to have accumulated too fast to be thoroughly redistributed by the waters. Only the stronger trees of the forest seem to have withstood the fierce storms of rocks that must have prevailed at the period of their entombment, as the smaller trunks and branches are prostrate or totally destroyed. In most cases where upright trunks penetrate the entire thickness of an enclosing bed, the tops may be seen to terminate with the upper surface of that bed, as if causes had acted at the beginning of the deposition of the succeeding stratum to plane down the irregularities of the old surface. In due course of time, this succeeding stratum produced its growth of forest, which followed its many predecessors into the subterranean depths, and in its turn was buried by the rapidly accumulating conglomerates. This remarkable alternation of events seems, in a general way, to have been kept up, from the beginning: to the end of the period.

The very precipitous character of the cliffs prevented me from reaching the upper part of the wall at this point, but I succeeded in making my way to the summit of the mountain at two other points, and found that everywhere the section was practically the same.

On the opposite side of the ralley the same conditions were observed: the fossil trees occur at the highest point reached, 3,000 fect above the river. The ranges that form the rim of this valley on the north and east reach an elevation of 11,500 feet, and as the conglomerates may be seen reaching and forming the loftiest summits without perceptible break or change of character, it is probable that they will be found to enclose the remains of forests throughout.

On some of the higher summits to the east of Yellowstone Lake, similar stratified conglomerates contain silicified wood in a very fraginentary state. These conglomerates are composed mainly of basaltic and trachytic materials, but contain large quantities of fragments of sandstones and quartzites, which leads to the conclusion that portions of the earlier Tertiary strata have been broken up and ejected with the igneous products. It is quite probable that these strata were among the later products of the Voleanic Tertiary age proper. They are generally found abutting against masses of unstratified igneous materials that probably mark the sites of islands which were doubtless volcanic centers. I find that as we recede from these centers of eruption the strata diminish very perceptibly in thickness and coarseness of materials, and have at the same time a very perceptible dip toward the surrounding valleys. One is at times led to suspect that portions, at least, of these beds are of subaërial formation, as is the case with extensive strata about the cones of modern volcanoes, but there are a multitude of facts that go to prove that the greater part of the formations of this age were rearranged or sedimented in water. 
As to the character of the seas or lakes in which the Volcanic Tertiary beds were laid down, it is clear that their waters were fresh, but as to their extent or distribution little is known. The formations cover or have covered an area of not less than 10,000 square miles, but they lie at a much greater elevation above the sea than the formations of synchronous lakes of neighboring provinces, and, so far as is known, have no actual connection with them.

It has been suggested by some one that these coarse volcanic strata may have been formed in very restricted bodies of water held high amongst the mountain ranges; but lakes cannot exist without barriers, and as has already been shown, the conglomerates, although naturally disintegrating more rapidly than any of the older rocks, now form the summits of many of the highest peaks that face the eastern plains, and the basins in which they were formed must have had free communication with the lowlands to the west, from the beginning to the end of the period.

For my present purpose it is sufficient to know that the bodies of water of this period were of sufficient extent not to be greatly affected in level by the filling-in of volcanic products or by the oscillations of the district under discussion, since we can have no correct measure of those oscillations of the surface which define the thickness and decide the character of strata without the barometer-like records of a sea-level.

The change of level produced by the great oscillation that preceded the Volcanic Tertiary period, and brought the lofty ranges of this region into existence, cannot fall far short of 20,000 feet. In order to reach these figures, we have but to add to the full thickness of the palæozoic and mesozoic strata the present elevation of the granitic ranges above the lowest observed stratum of the Tertiary rocks. At the beginning of the deposition of the Volcanic Tertiary rocks, however, the upward movement had ceased. The land had undergone enormous erosion, and subsidence had commenced. The great ranges that had lifted their erests to such lofty heights were again sinking beneath the sea. This subsidence did not cease until all, or nearly all, of the mountain peaks were submerged. It is in the strata deposited during this great subsidence that we must look for evidences of conditions and events that made the entombment and preservation of a vertical mile of forests possible.

The Yellowstone Valley, from the head of East Fork to the Lower Cañon, is carved out of strata which were formed along the west and south bases of the main eastern range of mountains. In many places the river has penetrated the full thickness of Tertiary strata, and has cut down into bodies of metamorphic rocks that at the beginning of the age were promontories or islands. It is plain, therefore, that those parts of the tree-bearing strata examined, were deposited along a shoreline, or, at least, near the borders of the Tertiary lake. Over large districts there must have been, during the period of general stubsidence, a frequent alternation of land and sea. Land would have to exist while 
the forests grew and matured; water would have to cover the same area to deposit the succeeding stratum; and again this stratum would have to rise above the water before a second forest could grow. There are two ways in which this result could be brought about. In a district subject to such intense volcanic action as this must have been, a succession of minor oscillations might have been associated with the general subsidence, so that large areas of the lake border districts would be alternately above and beneath the sea, or, as was doubtless often the case, the shallow portions of the sea became filled up with the rapidly accumulating ejecta, and sub-aërial deposits of sufficient depth were laid down to allow the growth of forests, which, in time, were depressed by the general subsidence, to be buried by a succeeding stratum of the volcanic débris. But this latter method was not the ordinary one, as is attested by the fact that many of the forests have grown in beds of finegrained material that must have been formed beneath the surface of the water.

I shall, however, not attempt to pursue this matter farther until all the data and materials collected have been examined. A thorough study of the various volcanic rocks will probably throw much light upon this very interesting group of strata. 



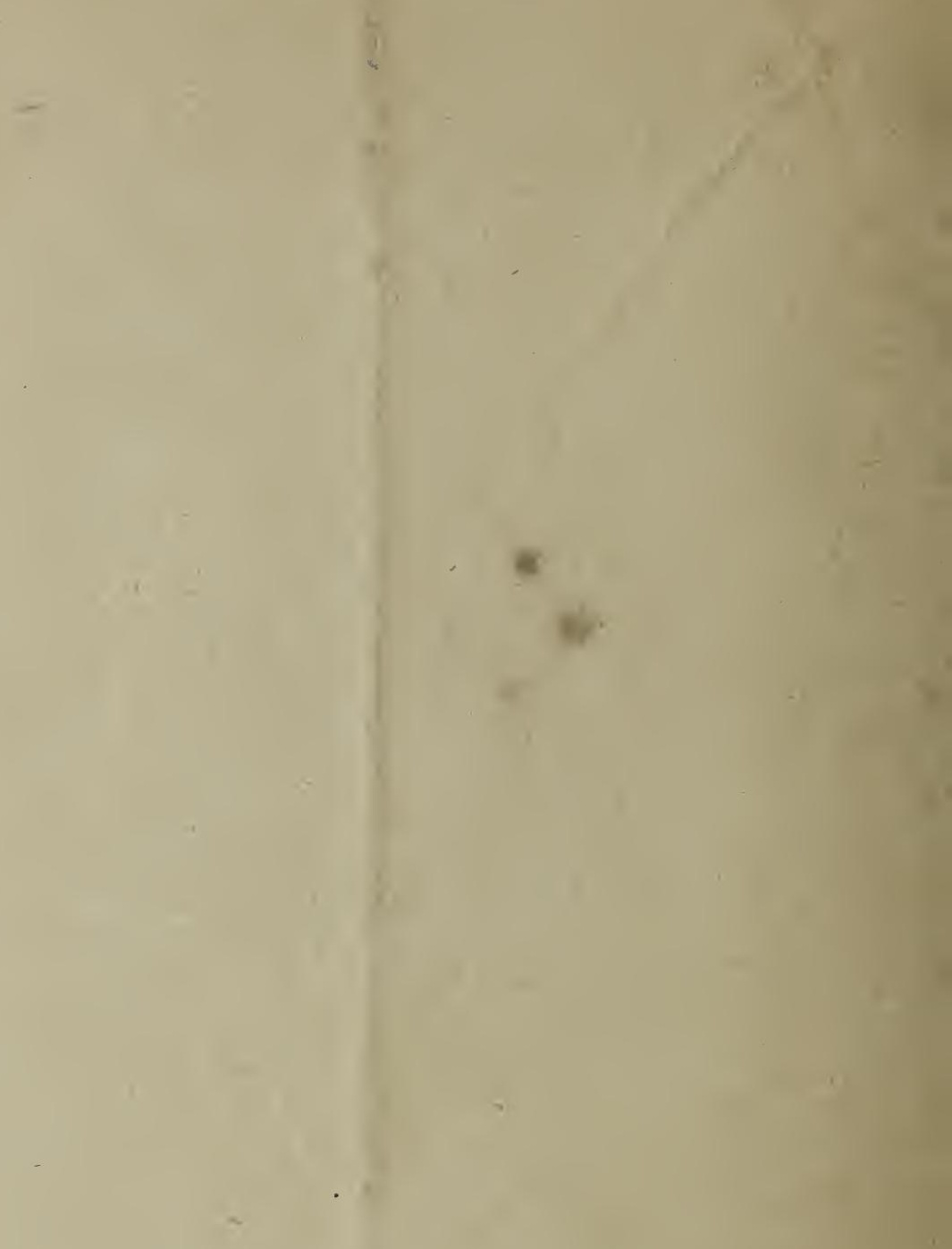

s.

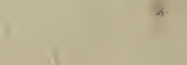

